\title{
Enerji Sektöründe Faaliyet Gösteren Bir İşletmede İş Sağlığı ve Güvenliği Yönetim Sistemi
}

\author{
Çetin Önder İNCEKARA ${ }^{1 *}$ \\ ${ }^{1}$ Dr., BOTAŞ Genel Müdürlüğü, Ankara, Turkey
}

Geliș Tarihi/Received: 21.01.2020

Kabul Tarihi/Accepted: 27.02.2020
Doi: doi.org/10.31200/makuubd.678400

Araştırma Makalesi/Research Article

\section{ÖZET}

Teknolojik gelişmeler sanayii sektöründe İş Sağlığı ve Güvenliği (İSG) Yönetim Sistemlerinin uygulamalarını artırmıştır. Bu kapsamda iş yerlerinde insana daha fazla değer vermeyi ve daha fazla İSG yatırımını gerekli kılmıştır. Endüstriyel tesislerde iş kazalarını, iş/meslek hastalıklarını önlemek amacıyla; işyerindeki olası risklerin belirlendiği, söz konusu riskleri kaldırmak için yasal yönetmeliklere/standartlara uyumlu uygulamaların yapıldı̆̆ 1 , gerekli iş/işbaşı İSG eğitimlerinin verilip uygulandığg, kontrol edildiği, iş yerinde acil eylem planlarının hazır olduğu, performansın izlendiği, düzeltici/iyileştirme faaliyetleri ile sürekli iyileştirme faaliyetlerinin yapıldığı, İSG faaliyetlerinin denetlendiği, gözden geçirildiği, sürekli iyileştirme yaklaşımı içerisinde olan bütün İSG çalışmalarının belli bir sistematik içinde dokümante edildiği bir İSG Yönetim Sistemi olan OHSAS 18001 uygulanmaktadır. Dünyada endüstriyel tesislerde en yaygın kullanılan/uygulanan standartlardan biri OHSAS 18001'dir. OHSAS 18001 uygulamaları ile tesislerde İSG riskleri sistematik yaklaşımla sürekli izlenerek azaltılmakta, performans göstergeleri/ölçümleri ve çalışanların aktif katılımı ile iş riskleri kontrol altına alınarak, izlenmekte ve iyileştirmeler yapılmaktadır. Çalışmada endüstriyel tesislerdeki OHSAS 18001 uygulamaları ve dikkat edilmesi gereken hususlar/adımlar tanımlanmış, tanımlanan adımlar kapsamında ülkemizdeki uluslararası bir enerji tesisinin İSG yönetim sistemleri uygulamaları değerlendirilmiştir. Tesiste kaza risklerini düşürmek için Karar Vericilerle (KV) görüşülmüş; alınması gereken eylemler, alınması gereken ilave tedbirler için çok kriterli karar verme (ÇKKV) yöntemlerinden Analitik Hiyerarşi Prosesinden (AHP) ve TOPSIS (The Technique for Order of Preference by Similarity to Ideal Solution) yöntemlerinden faydalanılmıştır. 
Incekara, Ç. Ö.

Anahtar kelimeler: İş Sağlığı ve Güvenliği Yönetim Sistemi, Endüstriyel Tesisler, Risk Değerlendirmesi, Risk Düzeyi, AHP/TOPSIS.

\title{
Occupational Health and Safety Management System in One of the Company Operating in Energy Sector
}

\begin{abstract}
Technological developments have increased the applications of Occupational Health and Safety (OHS) Management Systems in the industrial sector. In this context more attention is given to workers in workplaces and related OHS investments will be increased. In order to prevent exposure to OHS accidents/diseases in industrial plants OHS Management System which is OHSAS 18001 is applied; i.e. to identify possible risks to create a healthy and safe working environment, to create and implement programs in accordance with legal regulations/legislations/standards to eliminate the risks, to give appropriate on-the-job OHS trainings, to be ready for emergencies at the workplace, to monitor performance, to improve activities with continuous improvements, to audit and review OHS activities and studies within the framework of continuous improvement approach are documented in a systematic manner. OHSAS 18001 is one of the most widely used standard in industrial plants in the world. With the help of OHSAS 18001 applications, OHS risks in plants are continuously monitored and reduced by systematic approach; performance related risks are monitored and related improvements are made by using performance indicators/measurements and by active participation of employees. In this study, OHSAS 18001 applications in industrial plants and the related issues/steps to be considered are defined and within this scope, one of the international energy facility in Turkey is evaluated. Analytical Hierarchy Process (AHP) and TOPSIS (The Technique for Order of Preference by Similarity to Ideal Solution), which are multi-criteria decision making (MCDM) methods, are used to define/reduce accident risks and additional measures to be taken at the facility by conducting interviews with Decision Makers (DM).
\end{abstract}

Keywords: Occupational Health and Safety Management System, Industrial Plants, Risk Assessment, Risk Level, AHP/TOPSIS. 


\section{GíRiş̧}

Günümüzde sanayii sektörünün en önemli sorunlarından birisi; işyerindeki İş Sağlığı ve Güvenlik (İSG) önlemlerinin yeterince alınmamasıdır. Bu kapsamda dünyadaki ilk İSG ile ilgili yasa; "Çırakların Sağlığı ve Morali" olup 1802 yılında İngiltere'de kabul edilmiştir. Yasa ile çalışma saati günde 12 saat olarak sınırlandırılmış ve işyerlerinin havalandırılması zorunlu hale getirilmiştir.

İşletmeler günümüzde İSG kurallarına uyması/uygulaması yasal bir zorunluluk olup işlerini/aktivitelerini buna dikkat ederek gerçekleştirmesi/yürütmesi gerekmektedir. $\mathrm{Bu}$ kapsamında işyerlerinde/tesislerde İSG kurallarını uygulamak üzere kalite ve çevre yönetim sistemleri (ISO 9001 ve ISO 14001) gibi İSG üzerine yoğunlaşmış ayrı bir standarda/yönetim sistemine ihtiyaç duyulmuştur. Bu gereksinim doğrultuda İngiliz Standartlar Enstitüsü-BSI; İSG standard1 OHSAS 18001 (OHSAS 18001, 1999: 352) geliştirmiştir.

Sağlıklı çalışma ortamları işte mutluluğun ön şartı olup bir iş yerindeki kaza ve ramak kalma sayıları, düzenli ve kaliteli bir çalışma ortamına sahip olması; o işyerinin yeni işe başlayacak çalışanlar/çalışanlar tarafından tercih edilmesinde önemli bir rol oynamaktadır. Günümüzde İSG ile ilgili kazalar şirketlerin imajlarını/değerlerini düşürmekte ve şirketlere ağır faturalar ödemeye mahkûm etmektedir. Günümüzde klasik "kalite" tanımı geçerliliğini yitirmiştir, artık "kalite" tanımının içinde İSG kavramı yerleşmiş hatta tanıma çevresel ve sosyal olgularda eklenerek anlamı daha da genişlemiştir. Günümüzde "kalite" kavramı; şirketlerin İSG mevzuatlarını ne kadar uyduğu/hareket ettiği, çalışanları için güvenli bir ortam sağlayıp sağlamadığı, çalışma ortamını sürekli denetlenip denetlemediği, iyileştirilip iyileştirilmediği sorgulanmakta, bu durum tercih nedeni olmaktadır.

Uluslararası Çalışma Örgütü (ILO) verilerine göre her 15 saniyede bir işçi işyerinde yeteri kadar İSG önlemi alınmaması nedeniyle hayatını kaybetmektedir (ILO, 2001: 342). Bu nedenle işletmelerin güvenli bir iş ortamını sağlanması/oluşturulması en önemli sorumluluklarından biridir. Bu kapsamda ülkemizde 6331 sayılı İSG Kanunu ile şirketlerin risk analizi yapmaları, işyerlerini çalışanlar için sağlıklı ve güvenli hale getirmeleri, işyerlerini İSG kurallarına uyarak/uygulayarak güvenli hale getirmeleri yasal bir zorunluluktur.

\section{OHSAS 18001: İŞ SAĞLIĞI VE GÜVENLİĞİ YÖNETIMM SİSTEMİ}

İşverenler işyerlerinde İSG kurallarını uygulamak/takip etmek yasal bir zorunluluk olması sebebiyle işyeri risklerini azaltmak, çalışanlarına güvenli bir işyeri sağlamak için 
önlemler almak için bir sistem dahilinde takipler/iyileştirmeler yapmalıdır, bu sisteme İSG Yönetim Sistemi (İSGYS) denir. İSGYS; işyerindeki/tesisteki İSG aktivitelerini şirketin stratejisine/politikalarına uyumunu kontrol ederek gerekli düzeltmeleri/iyileştirmeleri sürekli yapan bir bakış açışıyla (PUKÖ Döngüsü ile) İSG problemlerinin/gözlemlerinin çözümlenmesi için bir araçtır.

ISGYS; tesislerde/işyerinde hem mer'i mevzuatlara uyulmasını hem de PUKÖ Döngüsünün kullanılması ile tesisteki iş verimliliğini/performansını/iyileştirmelerin devamlı denetlenmesini garanti altına almış oluruz. Bu kapsamda İngilizler-BSI (British Standarts Institute) 1999'da OHSAS (Occupational Health and Safety Assessment System) 18001 İSG Yönetim Sistemi Standardı (İSGYS) geliştirmiştir. OHSAS 18001 İSGYS; hem şirketlerin İSG ile ilgili mer'i mevzuatlara uyulması sağlanırken, tesisin ISG açısından devamlı denetlenmesi ile tesisteki üretkenliğin, verimliliğin artması sağlanmış olacaktır.

OHSAS 18001 İSGYS; işyerindeki/tesisteki İSG güvenliğinin değerlendirildiği, önlemlerin alındığı, sürekli iyileştirilmelerin yapıldığı, tesiste uymakla yükümlü olunan yasal mevzuatlara uyulduğu, İSG ile ilgili şirket hedeflerinin olduğu, İSG faaliyetlerine gereken önemin verildiği/denetlendiği, İSG spesifikasyonlarının kullanıldığı/verildiği bir sistemin kurulmasını garanti eder. OHSAS 18001 İSGYS diğer uluslararası Kalite ve Çevre Yönetim Sistemleri ile uyumludur.

Endüstriyel tesislerde; değişen yasal mevzuatlara uyum sağlamak, değişiklikleri takip etmek ve iş gücünü koruyarak işle ilgili risklerin yönetilebildiği bir İSGYS uygulanmalıdır. OHSAS 18001 ISGYS; şirketlerin ISG gerekliliklerini belirlemesine/tanımlamasına/ denetlemesine/izlenmesine, iş risklerinin azaltılmasına yardımcı olur. OHSAS 18001 İSGYS ile şirketler;

- Tesisteki İSG ile ilgili risklerinin belirlendiği ve yönetildiği, azaltılmasını/indirgenmiş olmasin1,

- Endüstriyel tesis ile ilgili mevzuat, yasa ve kanunların gerekliliklerini yerine getirerek dünya Standardlarını yakalanmış olmasını,

- ISG sistemine yönelik hedefleri belirlemiş ve bu hedeflere ulaşmak için yönetim programlarının geliştirilmiş olmasını,

- Tesiste gerekli eğitimleri uygun kişilere verilmesinin sağlanmış olmasını,

- Tesisteki acil durumlara (kazalar, yangın, vb) yönelik gerekli hazırlıkların yapılmış olmasin1, 
- İSG performasının izlenmesini, buna bağlı olarak gerekli düzeltici/iyileştirici faaliyetlerin yapılmasını,

- Kârlılığını artırılmış olmasını,

- İSG sistemi ile şirket içi motivasyon ve katılımın artmış olmasını,

- ISG faaliyetlerinin sistematik olarak yayılmasını ve bir Kurum kültürü olmasını sağlandığgnı,

- Düzeltici, önleyici faaliyetlerin yapıldığını,

- Tesis içi tehlike tanımlama ve risk değerlendirilmesinin yapılmış olmasını,

- Acil durum yönetim prosedürünün yapıldığını ve uygulanmasını,

- Organizasyon, yetki ve sorumluluklarının dağıtılmasını ve denetlenmesini,

- İSG konusunda denetimlerin/iç denetimlerin yapılmasını,

- Tesis içinde iş risklerinin değerlendirilmesinin yapıldığı,

- Şirkette/tesiste sıfır iş kazası, sıfır meslek hastalığı hedefinin benimsenmesini sağlayarak bu kapsamda gerekli önlemlerin alınması suretiyle verimliliğin arttır1masin1,

- İSG bilincinin oluşturulması ve geliştirilmesi için eğitim faaliyetlerinin düzenlenmesini,

- İş kazaları konusunda bilinçlendirerek azaltılmasının sağlanmasını,

- İSG risklerinin denetlenmesini, önlemlerinin alınmasını, ilgili iyileştirmelerin yap1lmasin1,

- İş kazaları sebebiyle işgücü kaybını ve ilgili risklerin azaltılmasını,

- Risk Değerlendirme Ekibinin kurulmasını,

- Bu kapsamda şirketin imajının güçlendirilmesini,

- Tesiste İSG önlemlerinin, planlarının oluşturulmasının sağlanmasını,

- Sahadaki çalışandan en üst düzey yöneticilere kadar bütün çalışanların katılımıyla İSG kapsamında görüşlerinin alınarak şirket içi bir öneri sisteminin geliştirilmesini/oluşturulmasını,

- Düzenli sağlık kontrollerinin yapılmasını,

- Tesisin İSG açısından sürekli denetlenmesini,

- Tesis içinde bulunan tehlikeli/basınçl1/elektrikli ekipmanların sürekli kontrol edilerek ilgili testlerinin yapılmasını,

- İSG eğitim programının uygulanmasını,

- Endüstriyel tesislerde yasal mevzuatın talep ettiği sürelerde yapılan eğitimlerin yap1lmasin1, 
- Acil durumlara hazırlıklı olunmasını: Acil durumlarda anında müdahale prosedürlerüne ve eğitimli Acil Durum ekiplerine sahip olmasını,

- ISG yönelik çalışmaların dokümante edilerek, sonuçlarının kayıt altına alınmasını,

garanti altına almış olacaktır (Frick, 2000: 73; Fernandez-Muniz, vd., 2007: 56; Fahlbruch, 2002: 347; Goosen, 2005: 138; İSGİP, 2013: 58). İSG Yönetim Sistemi'nin şirketlere/kurumlara sağladığg faydalar aşağıda sunulmuştur (NSC, 1980: 67; UCL, 2000: 431; Waeyenbergh, 2002: 301):

- Tesisin/işyerinin kazasız ve güvenli olması,

- İşçilerin motivasyonunun artması,

- Kaza/hastalık sebebiyle oluşacak kayıpların minimize edilerek, verimliliğin/performansın artması sağlanarak bu kapsamda oluşacak maliyetlerin düşmesi,

- Tesiste İSGYS kapsamında alınan tedbirler ile olası kazaların/risklerinin azalması,

- Çalışanların İSG bilgisine/kültürüne/görev bilincine sahibi olması,

- İSG sistemine sahip olunması ile rakiplerine karşı üstünlüğe sahip olması,

- Uluslararası alanlarda, resmi makamlar önünde; şirketin iş güvenliğine olan duyarlılığının bir göstergesidir.

6331 sayılı İSG Kanunu, 4857 sayılı İş Kanunu ile 2872 sayılı Çevre Kanunu ve bu kanunlara bağlı olarak çıkarılan yönetmelik vb. gereği bir endüstriyel tesiste;

- Tesiste kazaların önlenmesi/azaltılması kapsamında tesiste İSG önlemlerinin alınması,

- Çevresel etkinin en az düzeyde tutulmasına yönelik önlemler alınması,

- Gerekli dokümantasyonun hazırlanması,

sağlanmalı ve iş süreçlerindeki tüm faaliyetlerin bu doğrultuda planlanmasi/gerçekleştirilmesi gerekmektedir. Bu kapsamda endüstriyel tesislerde Kalite, Çevre ve İSG sorumlusu/sorumluları iş kazaları ve meslek hastalıklarının önüne geçilmesi için saha/tesis çalışmalarında aktif rol üstlenirler. Tesislerde çalışan personellerin sağlığını riske sokmayacak şekilde tüm önlemler alınmalıdır, bu kapsamda endüstriyel tesislerde dikkat edilmesi gereken İSG kuralları/uygulamaları (Goetsch, 2008: 125; Jallon vd., 2011: 238; Walter, 2000: 284; Wang, 2010: 129; Wassell, 2008: 247; WF, 2007: 335) aşağıda sunulmuştur: 
- Çalışanların tehlikeli hareket yapmaları engellenecek olup çalışanlar tesiste sürekli takip edilip eğitilmelidir.

- Çalışanlar etkin/aktif bir şekilde İSG faaliyetlerine katılmalıdır.

- Tesisteki riskler takip edilmeli, risk seviye tehlikeli düzeyde ise çalışma durdurulmalidir.

- Tesisteki kaldırma ekipmanları ve bu kapsamda kullanılan iş makinelerinde sonradan eklenen kancaların, ilgili teknik personel tarafından uygunluğu hakkında Makine Mühendisleri Odasından uygunluk raporu (test raporu) olmalıdır ve kancaların emniyet mandalları bulunmalıdır.

- Kaldırma ekipmanlarının (hi-up, vinç, side-boom) periyodik kontrolleri yapılmalıdır.

- Tesiste makinaların/ekipmanların basınç altındaki hortumlar ve bağlantı yerleri iyi durumda olduğu sürekli kontrol edilmelidir.

- Elektrikli aletlerin günlük ve periyodik kontrolleri yaptırılmalıdır.

- Operatörler askıda malzeme varken iş makinalarını terk etmemelidir.

- Tesisteki personelin eğitimleri tam olacaktır, düzenli olarak eğitimleri kontrol edilmelidir.

- Tesiste radyasyon kaynağı (varsa) için "Tehlike Durum Planı" hazırlanmalıdır.

- İş makinalarına ve gerekmesi durumunda yol geçişlerine işaretçi/bayrakçı konulmalıdır.

- Yüksekte yapılan çalışmaların risk çalışması yapılmalı, ekipmanları kontrolleri/bakımları yapılmalıdır.

- Elektrik panolarında koruma topraklaması düzenli olarak kontrol edilmelidir.

- Elektrik hatlarının/kablolarının kontrolleri düzenli olarak yapılmalıdır.

- Tesisteki tüm jeneratörlerin bakımı ve topraklaması yapılmalıdır.

- Tesiste yangın söndürme cihazları yeterli sayıda olacak ve periyodik bakımları yapilmalidir.

- Tesiste yangın boru hattı sistemi kurulmalıdır.

- Tesisteki tüm kimyasal maddelerin Güvenlik Bilgi Formları (GBF) şantiyede bulunacak ve kimyasallar bu koşula göre depolanmalıdır.

- Tesiste tahribatsız muayene (Non-Destructive Test: NDT) çalışmalarında (varsa) kullanılmak üzere radyasyon ölçüm dedektörü, dozimetreler, maşa, levha, güvenlik şeritleri olmalıdır. NDT sahasına izinsiz girişleri önlemek için uyarı levhaları konularak güvenlik şeritleri çekilmelidir. 
- NDT çalışmalarında görevli çalışanların dozimetrelerinin iki ayda bir doz ölçümüne gönderilmelidir.

- Tesisin düzenli olarak genel kontrolü yapılmalı, güvensiz yerlerde/bölgelerde/işlerde çalışma yapılmaması sağlanmalıdır.

- Tesisin düzenli olarak İSG risk değerlendirmesi yapılarak ilgili düzeltici akviteler uygulanmalıdır.

- Tesisteki çalışmalar için iş izinleri prosedürü (ateş/kaynak çalışması, elektrik/elektronik sistemleri çalışması, gazlı ortam çalışması, inşaat ve yıkım işleri çalışması, kazı çalışması, mekanik sistemler çalışması, klima/kalorifer çalışması, seyyar ekipman ve nakliye çalışması, yüksekte çalışmalar, dar alan/kapalı alan çalışması, yüklenici çalışması vb) uygulanmalıdır.

- Çalışanların işe giriş ve periyodik sağlık muayeneleri yapılmalıdır.

- Gerçekleştirilecek İSG faaliyetlerinin yer aldığı yıllık çalışma planı hazırlanmalıdır.

- Tesiste çalışanlara işbaşı eğitimleri verilmelidir.

- Acil durum planı ve acil durum müdahale ekipleri oluşturulmalıdır.

- Tesisteki iş ekipmanlarının günlük/haftalık/aylık/üç ve altı aylık kontrolleri/muayeneleri yapılarak onarımları defterine işlenmelidir.

- Elektrikli/canlı hatlardaki çalışmalar uyarı-ikaz levha ve şeritlerinin kullanılmalıdır.

- Tesiste iş makinası çarpması/devrilmesi ihtimaline karşı dikkatli olunmalıdır.

- Tesiste elektrik ana ve tali panoların kaçık akım rölesi bulunduğunun ve elektrik panolarının topraklamasının yapıldığının kontrolü yapılmalıdır.

- Tesiste yüksek gürültü olabilecek yerlerde (kompresör, jeneratör vb.) işitme kaybını engellemek için kulaklık/kulak tıkacı kullanılmalıdır.

- Tüm tesis aktivitelerinde uygun KKD (Kişisel Koruyucu Donanım) kullanımı zorunlu olmalidir.

- Tesiste uyarı-ikaz levha ve şeritlerinin kullanımında emniyet renkleri dikkate alınmalıdır (Kırmızı: Yasak İşareti/Tehlike alarmı; Sarı: Uyarı işareti; Mavi: Zorunluluk işareti; Yeşil: Tehlike yok).

- Tesiste tel örgü ile çevrilmiş proses sahası ve riskli bölgeler (petrol, doğal gaz, yanıcı gazın olduğu bölgeler) gibi riskli çalışmaların yapıldığı çalışma bölgesi Tehlikeli Alanlar olarak kabul edilmektedir.

- Tesiste çalışanların ilgili İSG eğitimleri verilmeli, eğitimler yasal zorunluluk süreleri çerçevesinde yenilenmelidir. 
- Tesiste ağır yük indirme/yükleme yapılırken iş makinalarına ve yüke uzak durulmalıdır ve taşıma ekipmanı kontrol edilmelidir, çalışma sahasına önlemler alınarak (şeritler çekilerek...) girilmesi engellenmelidir.

- NDT işlemi sırasında denetimli alana kesinlikle girilmemesi, gözetimli alana ise gerekli durumlarda radyasyon korunma sorumlusunun refakati eşliğinde daha önceden belirlenen ilgili personel dışında kesinlikle sahada bulunulmaması sağlanmalıdır.

- Tesiste gerekli olan yerlerde/işlerde toz ve gaz maskesinin kullanılması zorunludur.

- İş makinası ve araç kullanan tüm çalışanların emniyet kemeri kullanmaları ve hız kurallarına uymaları zorunludur.

- Tesiste çalışma yapılacak bölgelerde (varsa) kanalın/şevin çökmesini engelleyici gerekli önlemler (iksa, şev yapılması, vb.) alınmalıdır.

- Tesiste çalışan yabancı uyruklu vatandaşların çalışması durumunda (varsa) ilgili mevzuata uygun çalıştırılmalıdır.

İSG Yönetim Sistemi kapsamında yapılması gereken önemli adımlar aşağıda sunulmuştur:

- Tesiste İSG Kurulları (İSG Üst ve Uygulama Kurulları), Acil Durum Yönetim Grubu ve Olay Komuta Sistemi (Yangın Olay Komuta Sistemi, Deprem Olay Komuta Sistemi...) ve ilgili planlar (Tahliye Plan1, Deprem Eylem Plan1, Acil Durumlar ve Müdahale Planı...) oluşturulmalıdır.

- Tesiste İSG Üst Kurulu'nun mevzuatta belirtilen kişilerden oluşturulması sağlanmalıdır.

- İSG Kurulu tesise uygun bir İSG iç yönergesi hazırlamalı, takip ederek, gerekli tedbirleri alınmalıdır. Burada amaç İSG konularında o işyerinde çalışanlara yol göstermelidir.

- Tesisteki tüm bakım/onarım çalışmaları İSG kurallarına uygun ve güvenli bir ortamda yapılması sağlanmalıdır.

- Tesiste İSG eğitimleri planlamalıdır.

- Tesiste İSG durumuyla ilgili yıllık raporlar (Değerlendirme Raporu, Çalışma Planı, Eğitim Programı...) hazırlanmalıdır, yapılan çalışmalar değerlendirilmelidir.

- Tesiste uygunsuzluk, olay, kaza veya risk değerlendirme sonucu tespit edilen eksiklerin Düzeltici Faaliyetleri değerlendirilmeli ve ilgili aksiyon planları oluşturulmalıdır.

- Tesiste Yangın Söndürme Ekibi, Tahliye Sorumluları belirlenerek, görevlendirilmelidir. Ayrıca Güvenlik Amiri, İşyeri Hekimi görevlendirilmelidir. 
İncekara, Ç. $\ddot{O}$.

- Çevresel Acil Durumlar ve Müdahale Bölümü'nün uygulanmasından/uygulatılmasından; Çevresel Acil Durum Ekibi sorumludur.

- Tesiste İSG Uygulama Kurulu toplantılarında; ISG hedefleri ve programı ile varsa aksiyonları, çözümlenemeyen düzeltici faaliyetler, İSG performans ölçme ve izleme sonuçları, İSG Risk değerlendirmesi sonucu belirlenen aksiyonlar ve gerçekleşmeleri ile fırsatlar, İSG Sağlık Konuları, İSG Yıllık Değerlendirme Raporu, Yıllık Çalışma Planı, Yıllık Eğitim Programı, İş kazaları ve ramak kala olayları, düzeltici aksiyonlar, uyulması gereken yasal mevzuat gereklilikleri görüşülmelidir.

- Tesiste acil durumda kullanılmak üzere Acil Durum Malzeme ve Araç Envanter listesi (yangın tüpü...) oluşturulmalıdır.

- Tesiste yer alan acil durum ekiplerini oluşturan personel sayıları İşyerlerinde Acil Durumlar Hakkında Yönetmelik uyarınca ve madde 5.4.'da yer alan ilkyardım ekibini oluşturan personel sayısı İlkyardım Yönetmeliği uyarınca belirlenen kriterlere uygun olmalidir.

- Arama ve Kurtarma Ekibi, Yangın Koruma Ekibi, Tahliye ve Haberleşme Ekibi, Yangınla Mücadele Ekipleri, İlk Yardım Ekibi, Acil Durum Haberleşme Listesi, Acil Durum Destek Kuruluşları Listesi, Acil Durum Sorumluları Listesi oluşturulmalıdır.

- Tesisteki acil durum planı oluşturulmalı, uygulanmalı (minimum 1/yıl), gerektiğinde revize edilerek yenilenmelidir.

- Tesiste tehlikeli alan olarak tanımlanmış lokasyonlarda bulunan tehlikelerin tespit edilmesi ve kontrol altına alınması ile ilgili faaliyetlerde bulunan, İSG sistemleri çerçevesinde tehlikeli alan içindeki faaliyetlerin yürütülmesini kontrol eden, devamlılığını takip eden ve bu alanlarda yürütülecek çalışmalar ile ilgili olarak gerekli önlemlerin alınmasını sağlayan bir sorumlu atanmalıdır.

- Tesiste İSG risklerinin değerlendirilmesi "Risk Değerlendirme Takımı/Ekibi" tarafından gerçekleştirilmelidir.

- Tesiste risk değerlendirme ekibinin yapacağı seçim doğrultusunda 5x5 Matris (Tehlike Büyüklüğü * Tehlike Sıklığı) veya Fine Kinney risk değerlendirme metotları kullanılmalidır.

- Tesiste tehlikeli alanlar; Zone 0 (Yüksek oranda patlayıcı gazın/buharının, devamlı veya uzun süreli bulunduğu ortam) ve Zone 1 (Yüksek oranda patlayıcı gazın/buharının, tamir/bakım/onarım kapsamında ortaya çıkan sızıntıların bulunduğu ortam) tanımlanmalıdır. 
- Tesiste periyodik muayeneler sürelerinde yapılmalıdır.

- Tehlike sınıfına göre; çok tehlikeli işlerde çalışanların yılda bir kez, az tehlikeli işlerde çalışanların beş yılda bir sağlık kontrolleri düzenli olarak yapılmalıdır.

- Gürültülü ortamlarda çalışanlara ve işyeri hekimince uygun görülenlere odiyometrik test yaptırılmalidir.

- Gazlı ve tozlu ortamda çalışanlara işyeri hekimince uygun görülen personelin uygun görülen aralıklarla "Solunum Fonksiyon Testi" ve "Akciğer Grafiği" ile kontrolü yaptırılmalidır.

\subsection{OHSAS 18001: 2008 İSG Yönetim Sistemi Kurulması Aşamaları}

2İSGYS; tesisin/işyerinin İSG kapsamında uymakla yükümlü olduğu mer'i mevzuatlar doğrultusunda, şirketteki/tesisteki İSG risklerini indirerek (mümkünse tamamen ortadan kaldırarak) çalışanlar için güvenli bir çalışma ortamı sağlayarak, İSG risklerini irdeleyerek/değerlendirerek/iyileştirerek, tesisin ISG yönetim sistemidir. Endüstriyel tesiste İSGYS kurulmasının amaçları/hedefleri aşağıda sunulmuştur (Chinniah vd., 2011: 136; Kamrahi, 1997: 142; Khanzode vd., 2012: 85; Laitinen, vd., 2013: 168; Marhavilas vd., 2011: 264; MIT, 2004: 462; Rantanen, 2010: 281; Robson, 2005: 342; Roslin, 2008: 413; Shikdar, 2003: 564; Tompkins vd., 2010: 483):

1. Çalışanları iş kazalarına karşı korumak/bilinçlendirmek: Tesisteki/işyerinde kaza riskini ortadan kaldırmak, kazasız/güvenli bir çalışma ortamı sağlayarak, iş kazalarına karşı bilinçlendirmek/önlemler almak İSG ilk amaçlarındandır.

2. Tesiste üretim güvenliğini garantiye almak: Tesiste İSG ile ilgili kazaları/hastalıkların önlemesi amacı doğrultusunda çalışma verimini artırarak, İSG kaynaklı risklerinin etkilerinin azaltarak (makul bir seviyeye indirerek) tesis üretiminin korunması İSG yönetim sistemi amaçlarındandır.

3. Tesis güvenliğini garantiye almak: Tesiste alınan önlemler ile endüstriyel tesisi risklerden/tehlikelerden/arızalardan koruyabilmek için/ortadan kaldırılması için İSG kapsamında alınan önlemler/tedbirler ile işletme güvenliği sağlanacaktır.

4. Şirketin itibarını zedeleyecek olaylardan kaçınmak: İş kazası, yangın olması durumunda şirket/tesis hakkında medyada çıkacak olan olumsuz haberlerin şirket itibarını zedelememesi durumu İSG yönetimine geçilmesi ile önlenecektir. 
Incekara, Ç. $\ddot{O}$.

Endüstriyel tesislerde OHSAS 18001 ISGYS kurulması aşamaları; tesisin mevcut durumunun tespiti (İSG riskleri/uygulamaları/kazaları/hastalıkları değerlendirilir, gerekçeleri irdelenir), İSGYS planı ile İSG eğitim planının oluşturulması (İSG sorumluları/planı/eğitim planı/çizelgesi/gözden geçirmeleri/ekibi belirlenir/tanımlanır), İSGYS kurulması (İSG tehlikeleri/risk değerlendirmeleri/acil durum prosedürü/planları/performans parametreleri hazırlanır), gerekli denetimlerin yapılması, yönetimin gözden geçirmesi aşamalarından oluşmaktadır.

\subsection{5x5 Matris Metodu: Risk Değerlendirmesi}

Endüstriyel tesislerde risk değerlendirme ekibinin yapacağ 1 seçim doğrultusunda $5 \times 5$ Matris (Tehlike Büyüklüğü*Tehlike Sıklığı) veya Fine Kinney risk değerlendirme metotları kullanılmaktadır. Risk Derecelendirme Matrisi Tablo 1' de verilmiş olup Tablo 1' de kullanılan Tehlike Büyüklüğü ve Tehlike Sıklığı kavramlarının tanımları aşağıda verilmiştir:

Tehlike Büyüklüğü (Şiddet): Tehlikenin gerçekleşmesi neticesinde insana, malzemeye, makineye ve çevreye verdiği zararın büyüklüğüdür.

Tehlike Oluşum Sıklığı (Olasılık): Tehlikenin belirli bir tesiste oluşma sıklığıdır. Tehlike oluşum sıklığı için ayrı bir 5x5 metodundan faydalanılır. Tehlike oluşum sıklığı en az bir tesis göz önüne alınarak değerlendirilir. Tesiste Oluşum Sıklığı çok nadir olmasına rağmen bakım zamanları geçmiş veya olma ihtimali çok yüksek olan tehlikeler için Oluşum Sıklığı Çok Yüksek olarak işaretlenmelidir. 
Tablo 1. Risk derecelendirme matrisi

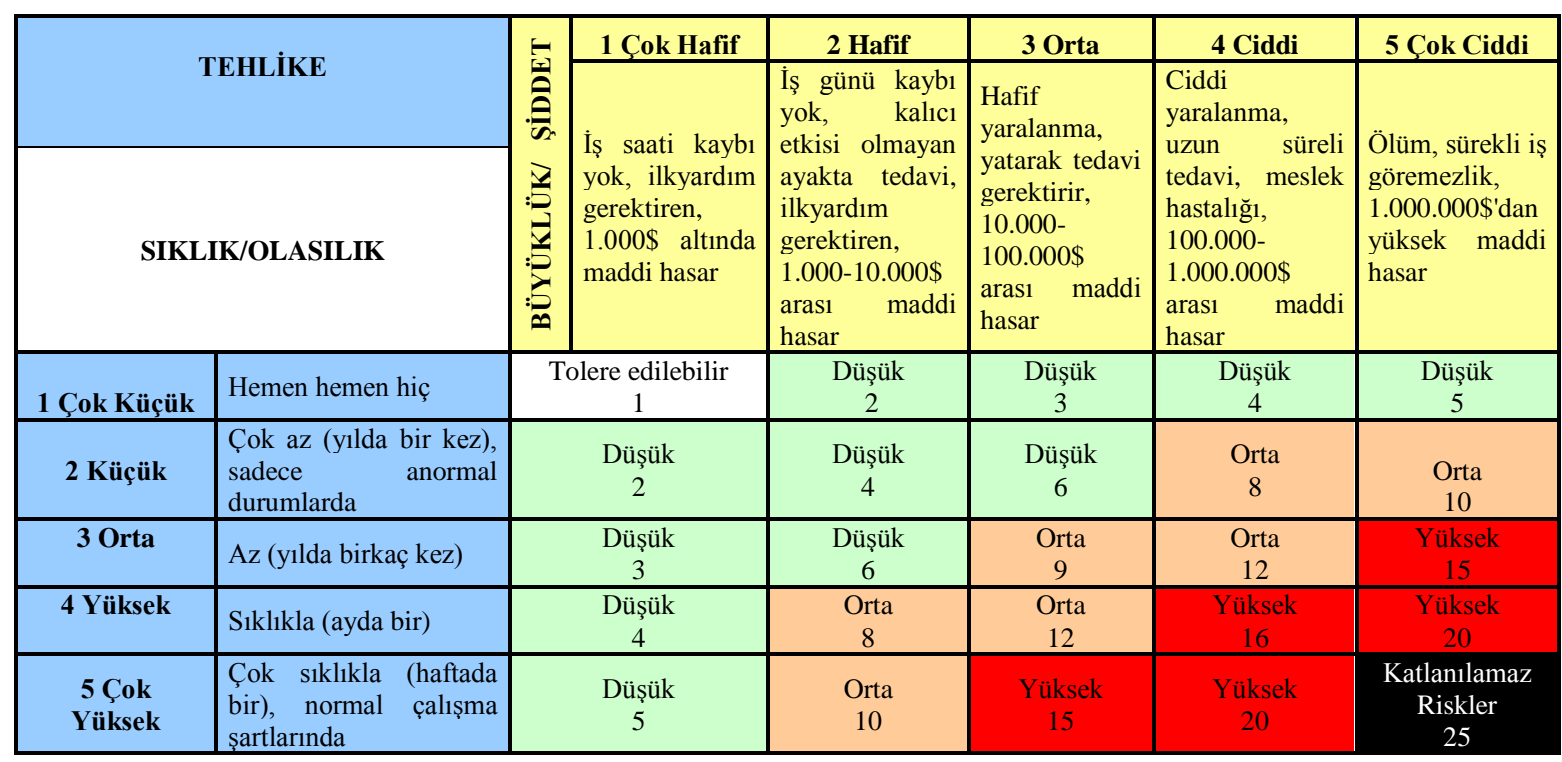

Kaynak: Garvey (1998: 21)

Risk Kontrol Sistematiği: Risk Derecelendirme Matrisi ile belirlenen risk büyüklüklerinin Tablo 2' de belirtilen yöntemler ile önceliklendirilerek kontrol altına alınması çalışmalarıdır. Risk kontrol yaklaşımı proaktif tespit ve izleme temellidir. Kontrol altına alma yöntemlerinin kullanılmasında kesin sınırları yoktur.

Tablo 2. Riski kontrol altına alma yöntemleri

\begin{tabular}{|c|c|c|}
\hline Risk Grubu & Açıklama & Kontrol Altına Alma Yöntemleri \\
\hline $\begin{array}{c}\text { Tolere } \\
\text { edilebilir (1) }\end{array}$ & $\begin{array}{l}\text { Tesis için tehlike arz eden } \\
\text { bir risk söz konusu değildir. }\end{array}$ & $\begin{array}{l}\text { Belirlenen riskleri ortadan kaldırmak için kontrol, iş başı bilgilendirme, } \\
\text { DF (Düzeltici Faaliyet İsteği) yapılmasına gerek olmayabilir. }\end{array}$ \\
\hline $\begin{array}{l}\text { Katlanılabilir } \\
\text { Riskler } \\
(2-6) \\
\text { (Dய̈ŞÜUK) } \\
\end{array}$ & $\begin{array}{l}\text { Rutin kontroller } \quad \text { ve } \\
\text { prosedürler } \\
\text { ettirilmelidir. }\end{array}$ & $\begin{array}{l}\text { Tespit edilen riskleri azaltmak için ilave önlemlere/kontrollere ihtiyaç } \\
\text { duyulmayabilir. Mevcut kontroller takip edilmeli/ denetlenmelidir. Isş } \\
\text { başı bilgilendirme, KKD ve uyarı levhaları, DF, doküman gereksinimi } \\
\text { vardır. }\end{array}$ \\
\hline $\begin{array}{l}\text { Orta } \\
\text { Düzeydeki } \\
\text { Riskler } \\
\text { (8-12) } \\
\text { (ORTA) } \\
\end{array}$ & $\begin{array}{lr}\text { Tespit edilen risklerin } \\
\text { azaltılması } & \text { için } \\
\text { faaliyetler/önlemler } \\
\text { alınmalıdır. }\end{array}$ & $\begin{array}{l}\text { Mekanik önlemler, KKD ile uyarı levhaları, eğitim, DF, doküman } \\
\text { gereksinimi, performans ölçümü ve izleme yapılmalıdır. }\end{array}$ \\
\hline $\begin{array}{c}\text { Önemli } \\
\text { Riskler } \\
(\mathbf{1 5 - 2 0 )} \\
\text { (YÜKSEK) }\end{array}$ & 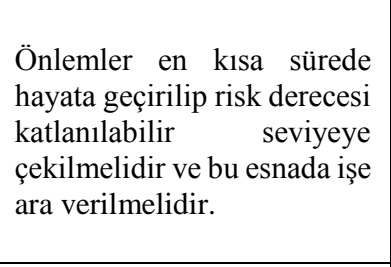 & $\begin{array}{l}\text { İş yapılırken risk devam ediyorsa önlemler alınmalıdır, önlemlerin işe } \\
\text { yarayıp yaramadığı kontrol edilmelidir. Buna göre aktiviteye devam } \\
\text { edilmeli veya ara verilmelidir. } \\
\text { Mekanik önlemler, tasarım ve iş akışı değişikliği, eğitim, KKD ve uyarı } \\
\text { levhaları, DF, doküman gereksinimi, acil durum planlaması ve tatbikatı, } \\
\text { çalışma koşullarının değişikliği, performans ölçümü ve izleme } \\
\text { yapılmalıdır. }\end{array}$ \\
\hline $\begin{array}{l}\text { Katlanılamaz } \\
\text { Riskler } \\
(\mathbf{2 0 - 2 5 )} \\
\text { (ÇOK } \\
\text { YÜKSEK) }\end{array}$ & $\begin{array}{l}\text { Önlemler en kısa sürede } \\
\text { hayata geçirilip risk derecesi } \\
\text { katlanılabilir seviyeye } \\
\text { çekilmelidir ve bu esnada iş } \\
\text { durdurulmalıdır. }\end{array}$ & $\begin{array}{l}\text { Aktiviteyle ilgili risk devam ediyorsa -önlemler yetersiz kalmışsa- işe } \\
\text { ara verilmelidir/durdurulmalıdır. Önlemler yetersiz kalıyorsa işe } \\
\text { başlanmamalıdır. Yatırım, eğitim, tasarım ve iş akışı değişikliği, } \\
\text { çalışma koşullarının değişikliği, performans ölçümü ve izleme ve riske } \\
\text { bağlı olarak diğer risk gruplarındaki önlemler alınmalıdır. }\end{array}$ \\
\hline
\end{tabular}

Kaynak: Garvey (1998: 22) 
Incekara, Ç. Ö.

\subsection{Fine Kinney metodu}

1976 yılında G.F. Kinney ve A.D Wiruth tarafından geliştirilen yöntem inşaat ve çimento sektöründe yaygın olarak kullanılmaktadır. Fine Kinney Metodu ile Risk Değeri;

$(\mathrm{R})=\mathrm{O} * \mathrm{~S} *$ Ş hesaplanır. Formülde yer alan O, S, Ş tanımları şöyledir (Kinney, 1976: 137):

$\mathrm{O}=$ Olasılık (0,2-10 arası bir değer alır.) Detay için bakınız Tablo 3.

$\mathrm{S}=\operatorname{Sıklık}(0,5-10$ arası bir değer alır.) Detay için bakınız Tablo 4.

Ş=Şiddet (1-100 arası bir değer alır.) Detay için bakınız Tablo 5.

"Olasılık" tanımı; zararın gerçekleşme ihtimalidir. Olasılık aşağıda sunulmuştur.

Tablo 3. Olasılık değeri ve açıklaması

\begin{tabular}{|c|l|}
\hline $\begin{array}{c}\text { Olasılık } \\
\text { Değeri (O) }\end{array}$ & \multicolumn{1}{c|}{ Açıklaması } \\
\hline 0.2 & Olasılık durumu: İmkânsız bir durumu ifade eder. \\
\hline 0.5 & Olasılık durumu: Zayıf ihtimalli bir durumu ifade eder. \\
\hline 1 & Olasılık durumu: Çok düşük ihtimalli bir durumu ifade eder. \\
\hline 3 & Olasılık durumu: Olma ihtimali çok az ama olabilir bir durumu ifade eder. \\
\hline 6 & Olasılık durumu: Kuvvetle Muhtemelen bir durumu ifade eder. \\
\hline 10 & Olasılık durumu: Çok Kuvvetli İhtimalle bir durumu ifade eder. \\
\hline
\end{tabular}

Kaynak: Kinney (1976: 137)

"Sıklık" tanımı; zarara/hasara/tehlikeye maruz kalma sıklığı olarak verilebilir. Sıklık Skalası Tablo 4' de verilmiştir.

Tablo 4. S1klık (maruziyet) skalas1

\begin{tabular}{|c|c|l|}
\hline Sıklık Değeri (S) & Olasılık Durumu & \multicolumn{1}{c|}{ Açıklaması } \\
\hline 0.5 & Çok çok az/nadir & Yılda bir veya daha az olabilir \\
\hline 1 & Çok az & Yılda bir veya birkaç kez olabilir \\
\hline 2 & Az bir ihtimalle & Ayda bir veya birkaç kez olabilir \\
\hline 3 & Bazen & Haftada bir veya birkaç kez olabilir \\
\hline 6 & Sıklıkla & Günde bir veya daha fazla olabilir \\
\hline 10 & Devamlı/Sürekli & Sürekli veya saatte birden fazla olabilir \\
\hline
\end{tabular}

Kaynak: Kinney (1976: 138) 
"Şiddet" tanımı; zararın/hasarın/tehlikenin gerçekleşmesi/olması durumunda çalışanlara/insana/tesise/işyerine verdiği hasar/zarar olarak verilebilir. Şiddet Derecesi Skalası Tablo 5' de verilmiştir.

Tablo 5. Şiddet derecesi (etki/zarar/sonuç) skalası

\begin{tabular}{|c|c|l|}
\hline $\begin{array}{c}\text { Şiddet Derecesi } \\
\text { Değeri (Ş) }\end{array}$ & Olasılık Durumu & \multicolumn{1}{c|}{ Açıklaması } \\
\hline 1 & $\mathrm{Az}$ & Önemsiz bir durum \\
\hline 3 & Önemli & Küçük hasarlı bir durum \\
\hline 7 & Çok Önemli & Önemli zarar veren bir durum \\
\hline 15 & Çok çok Önemli/Ciddi & Sakatlıklara sebep olan bir durum \\
\hline 40 & Çok Kötü & Ölümlü/Ağır etkisi olan bir durum \\
\hline 100 & Felaket & Birden çok ölümlü/çok ağır etkisi olan bir durum \\
\hline
\end{tabular}

Kaynak: Kinney (1976: 138)

\subsubsection{Risk değeri, karar ve eylem sistematiği}

Risk Değeri, $\mathrm{R}=\mathrm{O}$ x S x Ş olarak hesaplanır. Risk Değeri ve ilgili karar ile eylemler ve açıklamaları aşağıda sunulmuştur (Kinney, 1976: 140).

Tablo 6. Risk değeri

\begin{tabular}{|c|c|c|c|}
\hline No & Risk Aralığı/Değeri & Açıklaması & İlgili Eylemler \\
\hline 1 & $\mathrm{R}<20$ & $\begin{array}{l}\text { Kabul edilebilir bir risk } \\
\text { durumunu gösterir }\end{array}$ & Aktivite ile ilgili acil tedbirlere gerek yoktur. \\
\hline 2 & $20 \leq \mathrm{R}<70$ & $\begin{array}{l}\text { Kesin riskli bir durumu } \\
\text { gösterir }\end{array}$ & $\begin{array}{l}\text { Aktivite ile ilgili eylem planına ihtiyaç } \\
\text { vardır. }\end{array}$ \\
\hline 3 & $70 \leq \mathrm{R}<200$ & $\begin{array}{l}\text { Önemli riskli bir } \\
\text { durumu gösterir }\end{array}$ & $\begin{array}{l}\text { Aktivite dikkatle gözlenmeli, yıllık aksiyon } \\
\text { planlarının içine alınmalıdır. }\end{array}$ \\
\hline 4 & $200 \leq \mathrm{R}<400$ & $\begin{array}{l}\text { Yüksek riskli bir } \\
\text { durumu gösterir }\end{array}$ & $\begin{array}{l}\text { Aktivite ile ilgili eylemler kısa vadeli aksiyon } \\
\text { planına alınmalıdır. }\end{array}$ \\
\hline 5 & $\mathrm{R} \geq 400$ & $\begin{array}{l}\text { Çok yüksek riskli bir } \\
\text { durumu gösterir }\end{array}$ & $\begin{array}{l}\text { Aktivite ile ilgili eylemlere/çalışmalara } \\
\text { durdurulmalı, ivedi } \begin{array}{c}\text { olarak tedbirler } \\
\text { alınmalıdır. }\end{array}\end{array}$ \\
\hline
\end{tabular}

Kaynak: Kinney (1976: 140)

Yapılmış olan risk değerlendirmesi; risk/tehlike seviyesine göre değişmekte olup çok tehlikeli seviyede en geç iki yılda bir, tehlikeli seviyede dört yılda bir, az tehlikeli tesislerde altı yılda bir yenilenmelidir. 


\subsubsection{Bulanık Fine Kinney yaklaşımı}

Fine Kinney risk analiz yönteminde parametrelerinin puanlandırılması sırasında karşılaşılan belirsizliği ortadan kaldırmak için olasılık, frekans ve şiddet parametreleri bulanıklaştırılır ve karar kuralları oluşturulur. Bulanık Fine Kinney yaklaşımında olasılık, frekans ve şiddet parametreleri girdi; Risk Skoru değeri de çıktı olarak alınır. Çalışmada üçgen üyelik fonksiyonlarına sahip girdiler ve çıktı için oluşturulan karar kurallarında "Mamdani Bulanık Modeli Min Max” metodu kullanılmış olup (Mamdani, 1975: 13) Matlab Fuzzy Logic Designer programında kodlanmıştır. Olasılık, frekans ve şiddet girdileri ve Risk Skoru çıktısı için oluşturulan üçgen üyelik fonksiyonları ile oluşturulmuştur. Üyelik fonksiyonları oluşturulurken parametreye ait skala tablosunda bulunan bir alt ve bir üst değerden faydalanılmıştır.

\subsection{Uluslararası Enerji Tesisinin Risk Hesabı}

Çalışma kapsamında ülkemizdeki bir uluslararası enerji tesisinin risk değerlendirmesi yapılmıştır. Tesiste yapılan dolum çalışmasının Fine Kinney Metodu ile Risk Değerleri hesaplanmıştır. Tesiste riskli/çok tehlikeli bölgelerden biri olan dolum istasyonlarındaki dolum sırasındaki kıvılcım/kaza riskini (Zone 0: gazlı ortam) düşürmek için alınması gereken eylemler/önlemler Uzmanlar/Karar Vericiler (KV'ler) ile gözden geçirilmiş, ilave tedbirlerin değerlendirilmesi (uygulamada/sahada alınan tedbirler, riski ortadan kaldırma/indirme eylem planları, eylemlerin dikkatle izleme, var olan işaret ve uyarı levhalara yenilerinin eklenmesi, saha uygulama planı (MoS) gözden geçirilerek ilaveler yapılması durumu) için Analitik Hiyerarşi Prosesinden (AHP) ve öncelik sıralaması için TOPSIS (The Technique for Order of Preference by Similarity to Ideal Solution) yöntemlerinden faydalanılmıştır. Bu kapsamda çalışmada 7 temel, ilgili 22 alt kriter önerilmiş, söz konusu kriterler değerlendirilmiştir. AHP, aktivite ile ilgili KV'lerin hem objektif hem de sübjektif düşünceleri dikkate alabilmekte, aktivite hedefleri/amaçları, kriterleri, alt kriterleri ve alternatif eylemler arasındaki ilişkiyi gösterip ilgili risklerin değerlendirilebildiği, mantıksal düşünceyle irdelenebildiği bir hiyerarşik yapıda modellenmesine/değerlendirilmesine olanak sağlamaktadır.

Çalışma kapsamında ülkemizdeki uluslararası bir enerji tesisinde kaza risklerini düşürmek için alınması gereken eylemler, alınması gereken ilave tedbirler, tesiste ilgili İSG kontrol formları/check-list oluşturulurken AHP ve TOPSIS yöntemlerinden faydalanılmıştır (AHP; ÇKKV yöntemler içinde çok sık kullanıldığından bu yöntem seçilmiştir). AHP yöntemi ikili karşılaştırmalar yöntemi olarak kabul edilmekte olup; yöntemde karşılaştırmalar KV'ler 
yardımıyla uzmanların tecrübelerini yansıtmakta olup karar verme aşamasında seçim kriterlerini (kriterleri/alt kriterleri) birleştirme seçeneğini sunan bir yöntem olduğu için literatürde çok sık kullanılmaktadır (İncekara, 2018: 186). Çalışmada değerlendirmeler/puanlamalar/karşılaştırmalar; enerji tesislerinde tecrübesi olan enerji konusunda uzman kamuda ve özel sektörde çalışan müdür, şef, başmühendis, mühendis, teknisyen/tekniker olan KV'ler tarafından (toplam 38 kişi ile görüşülmüşsür) AHP (Saaty, 1980: 83) (seçenekler/alternatifler arasında ikili karşılaştırmalarla 1-9 arasında bir değerle değerlendirilebilen bir yöntem olup çalışmada aktivite ile ilgili ikili karşılaştırma matrisleri, öncelik vektörleri, ilgili tutarlılık oranları $(\mathrm{CR})$ hesaplanmıştır $(\mathrm{CR}<0,10))$ ve TOPSIS yöntemleri (aktivite/eylem ile ilgili karar noktaları ile değerlendirme kriterleri yer alan karar matrisi(A) oluşturulmuş, normalleştirilerek standart karar matrisi oluşturulmuş, ağırlıklandırılmış, ideal (A+) ve negatif ideal (A-) çözümleri oluşturulmuş/hesaplanmış, ayrım ölçütleri hesaplanmış, ideal çözüme göre göreli çözüm hesaplanmıştır) kullanılarak oluşturulan/doldurulan anketler ve görüşmeler neticesinde değerlendirilerek/ önceliklendirilerek/ağırlıklandırılarak, söz konusu saha kontrol formları/listesi oluşturulmuştur. 1981 yılında Hwang ve Yoon tarafından geliştirilen TOPSIS (The Technique for Order of Preference by Similarity to Ideal Solution) yönteminin temelinde; karar noktalarının pozitif ve negatif ideal çözümden uzaklıklarının belirlenmesi (çözüm alternatifinin pozitif ideal çözüme en kısa, negatif ideal çözüme en uzak mesafe olması durumuna/çözümüne göre oluşturulmuştur) ve karar noktaları arasında bir sıralama yapılması yatmaktadır (Wang, 2009: $378)$.

1970’lerde Thomas L. Saaty tarafından geliştirilen AHP, birden çok kriter içeren karmaşık problemlerin çözümünde kullanılan bir karar verme yöntemi olup birden fazla kritere dayalı karar verme problemlerinin çözümünde yaygın olarak kullanılmaktadır. AHP, karar vericilerin karmaşık problemleri; problemin ana hedefi, kriterleri, alt kriterleri ve alternatifleri arasındaki ilişkiyi gösteren bir hiyerarşik yapıda modellemelerine olanak vermektedir. AHP' nin en önemli özelliği Tablo 7' de gösterilen ikili karşılaştırmalar ile karar vericinin hem objektif hem de sübjektif düşüncelerini karar sürecine dahil edebilmesidir. AHP yönteminde; bilginin, tecrübenin, deneyimin, bireyin düşüncelerinin ve önsezilerinin mantıksal bir şekilde birleştirildiği bir yöntemdir. AHP çok geniş bir uygulama alanına sahiptir ve pek çok karar probleminde etkin olarak kullanılmaktadır. AHP, bileşenleri arasında karmaşık ilişkiler bulunan sistemlere ait karar problemlerinde; sistemi alt sistemleriyle ilişkili hiyerarşik bir yapıda oldukça basitleştirerek ifade edip, sezgisel ve mantıksal düşünceyle irdeleyebilen ve bunların 
modellenmelerine olanak sağlayan bir yaklaşımdır. AHP yönteminde; birçok değerlendirme kriterin rol oynadığı karar problemlerinde, kriterlerin amaca katkısının belirlenebilmesi için kriter ağırlıkları hesaplanabilmekte, uygun karar alternatifi seçilebilmektedir.

Tablo 7. AHP-ikili karşılaştırma yönteminde kullanılan skala

\begin{tabular}{|c|c|}
\hline Dereceler & Tanım \\
\hline 1 & Eşit Önemli \\
\hline 3 & Biraz Daha Fazla Önemli \\
\hline 5 & Kuvvetli Derece Önemli \\
\hline 7 & Çok Kuvvetli Derece Önemli \\
\hline 9 & Aşırı Derece Önemli \\
\hline $2 / 4 / 6 / 8$ & Uzlaşma Değerleri \\
\hline
\end{tabular}

Kaynak: Saaty (1980: 83)

AHP'nin ilk adımında, karar problem hiyerarşik olarak düzenlenir. Karar probleminin ana hedefi, kriterler, alt kriterler ve alternatifleri hiyerarşik bir yapıda hazırlanır. İkinci adımda; karar kriterleri ve her bir karar kriterine göre karar seçenekleri ikili karşılaştırmalarla (Tablo 7) yapılarak değerlendirilir. Üçüncü adımda; kriterler için ikili karşılaştırma matrisi oluşturulur. Dördüncü adımda; öncelik veya ağırlık vektörlerinin hesaplanması için öncelikle ilişki matrisleri normalleştirilir. Beşinci adımda; alternatiflerin/kriterlerin göreceli önem düzeyleri bulunarak karşılaştırma matrisinin tutarlılığı hesaplanır. Tutarlılık oranı (CR) karar vericinin her kritere dayalı değerlendirme aşamalarında kullanılabilmektedir ve son kararın kalitesi ve geçerliliği açısından önemli bir kavramdır. Tutarlılığın test edilmesine imkân vermesi yönüyle AHP yöntemi diğer çok kriterli karar verme yöntemlerine göre daha güven vermektedir. Karar matrisinin tutarlı olabilmesi için $\mathrm{CR}<0,10$ olması istenir. $\mathrm{CR}$ ne kadar sıfıra yakınsa karşılaştırma sonuçları daha tutarlı olacaktır.

TOPSIS yönteminde alternatif çözüm noktasının pozitif-ideal çözüme en kısa mesafe ve negatif-ideal çözüme en uzak mesafede olacağı varsayımına göre oluşturulmuştur. TOPSIS yöntemi nitel bir çevrim yapılmaksızın, direkt veri üzerinde uygulanabilmektedir. TOPSIS yönteminin ilk adımında karar matrisi (A) oluşturulur. Karar matrisi oluşturulurken satırlarda üstünlükleri sıralanmak istenen karar noktaları, sütunlarda ise karar vermede kullanılacak değerlendirme kriterleri yer almaktadır. İkinci adımda karar matrisindeki (A) her bir değerin bulunduğu sütundaki değerlerin kareleri toplamının kareköküne bölünerek matris normalize edilir. R matrisi elde edilir. Üçüncü adımda öncelikle değerlendirme kriterlerine ilişskin ağırlık değerleri (wi) belirlenir. Sonrasında R matrisinin her bir sütunundaki elemanlar ilgili wi değeri ile çarpılarak Ağırlıklı Standart Karar Matrisi (V) matrisi oluşturulur. Değerlendirme 
kriterlerine ilişkin ağırlıklar (W) belirlenir. Oluşturulacak ağırlıklı normalize edilmiş karar matrisi için, R matrisinin sütunlarındaki değerler ilgili değerlendirme kriteri ağırlık değerleri ile çarpılarak V matrisinin sütunları hesaplanır. TOPSIS yöntemi, her bir değerlendirme kriterinin monoton artan veya azalan bir eğilime sahip olduğunu varsaymaktadır. Dördüncü adımda; ideal çözümün oluşturulabilmesi için ağırlıklı standart karar matrisindeki değerlendirme kriterlerinin yani sütun değerlerinin en büyükleri seçilir. Negatif ideal çözüm seti ise, ağırlıklı standart karar matrisindeki değerlendirme kriterlerinin yani sütun değerlerinin en küçükleri seçilerek oluşturulur. TOPSIS yönteminde her bir karar noktasına ilişkin değerlendirme kriteri değerinin ideal ve negatif ideal çözüm setinden sapmalarının bulunabilmesi için Euclidian Uzaklık Yaklaşımından yararlanılmaktadır. Beşinci adımda elde edilen alternatiflere ilişkin sapma değerleri ise İdeal Ayırım $\left(S_{i}^{*}\right)$ ve Negatif İdeal Ayırım $\left(S_{i}^{-}\right)$ ölçütü olarak adlandırılmaktadır. Altıncı adımda her bir karar noktasının ideal çözüme göreli yakınlığının $\left(C_{i}^{*}\right)$ hesaplanmasında ideal ve negatif ideal ayırım ölçütlerinden yararlanılmaktadır. Burada kullanılan ölçüt, negatif ideal ayırım ölçütünün toplam ayırım ölçütü içindeki payıdır.

Çalışma kapsamında ilk olarak tespit edilen kriterler AHP yöntemi ile ağırlıklandırılmış, sonrasında TOPSIS yöntemi ile çözümün alternatif çözümleri/yaklaşımları ideal çözüme yakınlık değerleri hesaplanarak, çözümlerin öncelik ilişkisi değerlendirilmiştir. Söz konusu alternatifler için ideal çözüm tablosu oluşturulmuş TOPSIS yöntemi kullanarak alternatifler sıralanmış ve tesise en uygun İSG kontrol formları/check-list maddeleri (önem sırasına göre) oluşturulmuştur. Problemin çözümünde Microsoft firmasının Excel programı kullanılmıştır. Tesisin risk değerlendirmesi ise; Risk Değeri(R) $=\mathrm{O} * \mathrm{~S} *$ Ş formülü ile (Fine Kinney Metodu ile) hesaplanmıştır. Burada;

$\mathrm{O}=$ Olasılık değeri olarak Tablo 3' ten "Kuvvetle Muhtemel" değeri olan 6 değeri almıştır. (Dolum işlemi çok sık ve sürekli olarak yapıldığı için olasılığı "Kuvvetle Muhtemel” değeri alınmıştır.)

S=Sıklık değeri olarak Tablo 4' ten “Sürekli” değeri olan 10 değeri almıştır. (Sürekli dolum işlemi yapıldı̆̆ 1 için)

Ş=Şiddet değeri olarak Tablo 5' ten "Felaket" değeri olan 40 değeri almıştır. (Dolum işlemi sırasındaki sızıntı, patlama bir çevre felaketine sebep olacağı için) 
Çalışmada risk analizi için ilk adımda tehlikeler KV'lerle birlikte saptanarak FineKinney yöntemi ile tehlikelerin risk puanları ve bu puanların karşılık geldiği risk seviyeleri belirlenmiştir. Daha sonra aynı uygulama bulanık Fine Kinney yöntemi (Bölüm 2.3.2. de detaylı anlatılan yöntem) ile tekrar hesaplanmıştır/değerlendirilmiştir. Değerlendirme sonucu "Risk Değeri” Tablo 6' a göre R>400 “Çok Yüksek Risk” olduğu için iş aktivitesi kapsamında çalışmaya ara verilerek derhal tedbir alınmıştır. Bu kapsamda "Riski Kontrol Altına Alma Yöntemleri” nde yer alan "Kontrol Altına Alma Yöntemleri” vasıtasıyla “Çok Yüksek Risk” seviyesindeki önlemler vasıtasıyla (alınan önlemler: mekanik önlemler, gerekli detay eğitimler, işbaşı eğitimleri, ilave KKD ve uyarı levhaları, DF, acil durum planlaması ve ilave tatbikatlar, çalışma koşullarının iyileştirilmesi, işbaşı performans ölçümü ve izleme) ile risk kontrol altına alınmış ve seviyesi “Önemli Riskler” seviyesine düşürülmüştür. Bu seviyede önerilen önlem; “Dikkatle izlenmeli ve yıllık aksiyon planına alınarak giderilmelidir”. Bu kapsamda işletmenin yıllık aksiyon planları revize edilmiş, söz konusu aktivite eklenmiştir. Tesiste uygulanan acil durum planının uygulama adımlarının ve ilgili iş aktivitesi risk analizlerinin üzerinden geçilmiş bu kapsamda tesiste yılda en az iki defa tatbikat yapılmasına karar verilmiştir. Ayrıca çalışma kapsamında sahadaki uygulamaların risk takip sistemi revize edilmiş ve operasyon sırasındaki risklerin azaltılması sağlanmıştır. Ayrıca iş aktivitesinin risk değerlendirmesi sonucu; aktivitenin "çok tehlikeli” sınıfta olduğu için işletmeci firma yetkilileri ile görüşülmüş ve yılda bir aktivite değerlendirmesinin yeniden yapılmasına/gözden geçirilmesine karar verilmiştir.

\subsection{PUKÖ Döngüsü}

İSG standard1; "Planla-Uygula-Kontrol Et-Önlem Al(PUKÖ)" yönetim metodolojisini temel alır. PUKÖ; William Edwards Deming tarafından geliştirilmiş olup toplam kalite yönetimi kapsamında pek çok çalışması mevcuttur. Deming; kalite kültürünün/yönetiminin bir şirket kültürü olması gerektiğini belirtmiştir. Deming tarafından geliştirilen PUKÖ döngüsü; şirket/tesis/ünite hedeflerinin ne ölçüde ulaşıldı̆̆ı/yakaladığı/iyileştirildiği tespit edilir. OHSAS 18001 İSG Yönetim Sistemi ile tesis içindeki yapılan uygulamalarda; yukarıdaki paragrafta detaylı anlatılan Toplam Kalite Yönetimi'nin temellerinden Şekil-1'de gösterilen PUKÖ döngüsü uygulanır. PUKÖ döngüsü tesiste devamlı iyileştirilmenin uygulanmasını garanti eder. 


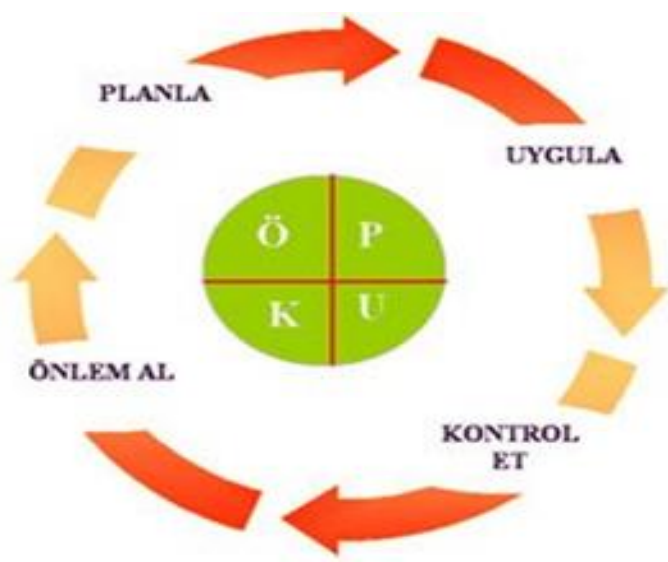

Şekil 1. PUKÖ Döngüsü

Kaynak: Deming (1982: 36)

OHSAS 18001 İSG Yönetim Sistemi şirketin/tesisin İSG performansı için sürekli iyileştirme sürecine (PUKÖ) odaklanır. Şekil 1' de gösterilen PUKÖ döngüsü kısaca aşağıda özetlenmiştir:

- Planla: İSGYS şirket/tesis üst yönetiminin desteği/sorumluluğu altında bir enerji politikası/hedefi oluşturularak, İSG çalışma ekibi kurulması sağlanır. Şirketin/tesisin belirlenen İSG politikasına uygun olarak; tesisteki İSG performans göstergeleri, hedefler/amaçlar ile aksiyon planları oluşturulur.

- Uygula: Tesiste İSGYS hedef ve süreçleri doğrultusunda oluşturulan İSG yönetim faaliyet planları uygulanır. Bu adımda şirket/tesis planlarının çalışanlar, üst yönetim, denetleyenler tarafından uygulanması sağlanır.

- Kontrol et: Tesiste İSGYS ile ilgili yapılan değişikliklerin/uygulamaların kontrol edildiği/değerlendirildiği bir adımdır/süreçtir. Şirket İSGYS politikasına ve hedeflerine uygun İSG performansını belirleyen/değerlendirilen temel karakteristikleri, süreçleri tanımlanır, ilgili kontrol noktalarının raporları oluşturulur.

- Önlem al: Tesisin İSGYS performansı; şirket enerji politikaları kapsamında alınması gereken düzeltici işlemler/önlemler bu adımda tanımlanmıştır.

OHSAS 18001 İSG Yönetim Sistemi standardı; PUKÖ metodolojisi ile şirket/tesis içi günlük uygulamaları denetleyerek, iyileştirir.

\section{SONUÇ VE ÖNERILER}

Endüstriyel tesislerde; İSG performansları, kazalar/hastalıklar, tehlikeli durumlar/ aktiviteler, düzeltici/iyileştirici işlemler kayıt altına alınmalı, sonuçlarının, verileri 
kaydedilmeli, tesiste sürekli iyileştirmeler yapılmalıdır. OHSAS 18001 İSGYS; endüstriyel tesislerde gerekli önlemler alınarak, hedeflere ulaşılması izlenir, İSGYS sürecinin performansı, işletme kriterleri ve tesisin uymakla yükümlü olduğu yasal mevzuat şartlarını ve uygunluğunu izleyen proaktif tedbirleri içerir.

Endüstriyel tesislerde OHSAS 18001 İSGYS uygulanmaktadır. İSG yönetim sistemi; İSG hedeflerine ulaşılması için riskleri bir sistem dahilinde ele alır, kontrol eder, performansını takip eder. İSGYS için gönüllük esas olmasına rağmen endüstriyel tesislerde (yüksek kaza oranları ve risklerinden dolay1...) uygulanması bir zorunluluktur ve uygulama adımları/uygulamaları sıkı bir şekilde kontrol (hem tesisteki İSG ekipleri hem de dışarıdan üçüncü taraf muayenesi (third party inspection) firmaları vasıtasıyla) edilmelidir. OHSAS 18001 İSGYS tesisin/işletmenin kendi ihtiyaçlarına uygun prosedür ve düzenlemeler geliştirmesi gerekmektedir. İSGYS standart şartları, yasal ve ilgili mevzuatları (sektörel şartlar...) dikkate alarak; tesiste bulunan tehlike, risk ve ISG fırsatlarını tespit etmeyi, riskleri ortadan kaldırmayı veya gerekli önlemleri alarak kabul edilebilir risk seviyesine indirmeyi, olay ve kazaların yaşanmasını engellemeyi hedefler. İSGYS kapsamında her endüstriyel tesislerde; İSG ekipleri tarafından tesisteki tehlikeler tespit edilerek ilgili adımlar doğru olarak uygulanmalı; uygulamalar periyodik aralıklarla gözden geçirilmeli, değişen şartlara ve tesise göre geliştirmeli, çalışanların riskleri ve İSG fırsatlarını görebilme yeteneği geliştirilmelidir.

Endüstriyel tesislerde İSG kapsamında uymakla yükümlü olduğu mer’i mevzuatlar doğrultusunda, şirketteki/tesisteki İSG risklerini indirerek, çalışanlar için güvenli bir çalışma ortamı sağlayarak, İSG risklerini irdeleyerek/değerlendirerek/iyileştirerek, İSG yönetim sistemi kurulmalıdır. Burada amaç çalışanları iş kazalarına karşı korumak/bilinçlendirmek, tesiste üretim güvenliğini ve tesis güvenliğini garantiye almak, şirketin itibarını zedeleyecek olaylardan kaçınmaktır.

Çalışma kapsamında ülkemizdeki bir uluslararası enerji tesisinde kaza risklerini düşürmek için alınması gereken eylemler, alınması gereken ilave tedbirler, ilgili İSG formları/check-list/kontrol listesi oluşturulurken çok kriterli karar verme (ÇKKV) yöntemlerinden AHP ve TOPSIS yöntemlerinden faydalanılmıştır. (ÇKKV yöntemler içinde AHP çok sık kullanıldığından bu yöntem seçilmiştir). AHP yöntemi ikili karşılaştırmalar yöntemi olarak kabul edilmekte olup; yöntemde karşılaştırmalar KV'ler yardımıyla uzmanların tecrübelerini yansıtmakta olup karar verme aşamasında seçim kriterlerini (kriterleri/alt kriterleri) birleştirme seçeneğini sunan bir yöntem olduğu için literatürde çok sık 
kullanılmaktadır (İncekara, 2018: 186). Çalışmada değerlendirmeler/puanlamalar/ karşılaştırmalar; enerji tesislerinde tecrübesi olan enerji konusunda uzman kamuda ve özel sektörde çalışan müdür, şef, başmühendis, mühendis, teknisyen/tekniker olan KV'ler tarafından (toplam 38 kişi ile görüşülmüştür) AHP skalası:1-9 skalasına göre (Saaty, 1980: 83) doldurulan anketler ve görüşmeler neticesinde değerlendirilerek/önceliklendirilerek/ ağırlıklandırılarak, söz konusu formlar oluşturulmuştur. TOPSIS yöntemi (aktivite/eylem ile ilgili karar noktaları ile değerlendirme kriterleri yer alan karar matrisi(A) oluşturulmuş, normalleştirilerek standart karar matrisi oluşturulmuş, ağırlıklandırılmış, ideal (A+) ve negatif ideal (A-) çözümleri oluşturulmuş/hesaplanmış, ayrım ölçütleri hesaplanmış, ideal çözüme göre göreli çözüm hesaplanmıştır) ile çözümün alternatif çözümleri/yaklaşımları ideal çözüme yakınlık değerleri hesaplanarak, çözümlerin öncelik ilişkisi değerlendirilmiştir. Söz konusu alternatifler için ideal çözüm tablosu oluşturulmuş, TOPSIS yöntemi kullanarak alternatifler sıralanmış ve tesise en uygun İSG kontrol formları/check-list maddeleri (önem sırasına göre) oluşturulmuştur. Tesis içindeki tehlike tanımlama ve risk değerlendirme faaliyetleri kapsamında tesisteki İSG gereksinimleri işin uzmanları vasıtası ile belirlenmiş, öncelikler değerlendirilmişs (çalışmada AHP/TOPSIS yöntemleri kullanılmıştır), dokümante edilmiş ve tesisin durumuna uygun olarak kontroller/revizyonlar yapılarak; çalışanlar için gerekli eğitimler planlanmış, tesis kontrollerinin geliştirilmesi adına önleyici bir yapı (proaktif bir anlayışla) ile yürütülmesi sağlanmıştır.

Endüstriyel tesisler için risk değerlendirmesi; risk/tehlike seviyesine göre değişmekte olup çok tehlikeli seviyede en geç iki yılda bir, tehlikeli seviyede dört yılda bir, az tehlikeli tesislerde altı yılda bir yenilenmelidir. Tesiste iş kazalarını önlemek için gerekli sorumluluk bilinci, birim sorumlularından başlayarak en alt birimde çalışanlara/tüm kademedeki personele verilmelidir. Çalışma kapsamında ülkemizdeki uluslararası enerji tesisinin risk/tehlike seviyeleri yeniden gözden geçirilerek, gerekli değişiklikler/düzenlemeler yapılmıştır.

Endüstriyel tesiste öncelikli olarak tehlikeli bölgeler/alanlar; Zone 0 ve Zone 1 bölgeleri belirlenmelidir/tanımlanmalıdır. Tesiste bu alanlara özel önlemler alınmalı, değerlendirilmeli ve personel konu hakkında bilgilendirilmeli, eğitilmelidir. Endüstriyel tesislerde tehlikeli alanlar/riskler; 5x5 Risk Matrisi ile Fine Kinney Metodu'na göre değerlendirilir. 5x5 Matris Metodunda tesisin risk değerlendirmesi; risk değerlendirme ekibinin "Tehlike Büyüklüğü" ve "Tehlike Sıklığı" puanlamasına göre Tablo 1' de yer alan "Risk Derecelendirme Matrisine" göre hesaplanır. Çıkan risk seviyesi Tablo 2'de yer alan "Riski Kontrol Altına Alma Yöntemleri" ile tesisin/aktivitenin risk seviyesi düşürülmelidir. Fine Kinney Metodunda tesisin 
risk değeri; R= O x S x Ş (R: Risk, O: Olasılık-Tablo 3, S: Sıklık-Tablo 4, Ş: Şiddet-Tablo 5) ile hesaplanır. Bu yöntemde hesaplanan "R: Risk Değeri"ne göre Tablo 6' da yer alan risk düşürme eylem planı uygulanmalıdır. Endüstriyel tesiste "riski düşürme eylem planı" kapsamında; alınacak önlemlerde öncelik hiyerarşisine uygun bir eylem planı (tedbirler alma/almama, ortadan kaldırma, mühendislik kontrolleri ve uygulamalar, ikame eylem yöntemleri/yolları, dikkatle izleme, işaret ve uyarı levhaları kullanma, saha kontrolleri, işe özel kişisel koruyucu donanım kullanma, detaylı uygulama planı (MoS) hazırlama ve uygulama, çalışmaya ara verme) ile riskin durumu ile ilgili "takip sistemi” oluşturularak risklerin azaltılması sağlanmalıdır. Tesisteki İSGYS performansı düzenli bir şekilde ilgili prosedürler doğrultusunda izlenmeli, ölçülmeli ve üst yönetime düzenli olarak raporlanmalıdır. Çalışma kapsamında ülkemizdeki bir uluslararası enerji tesisinin risk değerlendirmesi yapılmıştır. Tesiste yapılan çalışmaların; Fine Kinney Metodu ile (klasik ve bulanık yöntemler kullanarak) Risk Değerleri hesaplanmıştır. Çalışmada risk analizi için ilk adımda tehlikeler (KV' lerle birlikte) saptanarak Fine Kinney yöntemi ile tehlikelerin risk puanları ve bu puanların karşılık geldiği risk seviyeleri belirlenmiştir. Daha sonra aynı uygulama bulanık Fine Kinney yöntemi ile tekrar hesaplanmıştır/değerlendirilmiştir. Çalışmada üçgen üyelik fonksiyonlarına sahip girdiler ve çıktı için oluşturulan karar kurallarında "Mamdani Bulanık Modeli” kullanılmıştır (Mamdani, 1975: 13). Bu kapsamda tesiste riskli/çok tehlikeli bölgelerden biri olan dolum istasyonlarındaki dolum sırasındaki kıvılcım/kaza riskini (Zone 0: gazlı ortam) düşürmek için alınması gereken eylemler gözden geçirilerek, ilave tedbirler (uygulamada/sahada alınan tedbirler, riski ortadan kaldırma/indirme eylem planları, eylemlerin dikkatle izleme, var olan işaret ve uyarı levhalara yenilerinin eklenmesi, saha uygulama planı (MoS) gözden geçirilerek ilaveler yapılmıştır) irdelenmiştir. Değerlendirme sonucu "Risk Değeri”' Tablo 6' a göre R>400 “Çok Yüksek Risk” olduğu için iş aktivitesi kapsamında çalışmaya ara verilerek derhal tedbir alınmıştır. Bu kapsamda "Riski Kontrol Altına Alma Yöntemleri” nde yer alan "Kontrol Altına Alma Yöntemleri” vasıtasıyla “Çok Yüksek Risk” seviyesindeki önlemler vasıtasıyla (sahada alınan önlemler: mekanik önlemler, gerekli eğitimler, işbaşı eğitimleri, ilave KKD ve uyarı levhaları, DF, acil durum planlaması ve ilave tatbikatlar, çalışma koşullarının iyileştirilmesi, işbaşı performans ölçümü ve izleme) ile risk kontrol altına alınmış ve risk seviyesi "Önemli Riskler" seviyesine düşürülmüştür. Tesiste uygulanan acil durum planının uygulama adımları ve ilgili iş aktivitesi risk analizleri gözden geçirilmiş; bu kapsamda tesiste yılda en az iki defa tatbikat yapılmasına karar verilmiştir. Tesisin PUKÖ metodolojisi ile uygulamalar denetlenerek, sahadaki uygulamaların risk takip sistemi revize edilmiş, ilgili iyileştirmeler yapılmış ve operasyon sırasındaki risklerin azaltılması sağlamak amacıyla; işletmenin yıllık 
aksiyon planları revize edilerek, ilgili aktiviteler/eylemler/adımlar revize edilmişstir. Ayrıca iş aktivitelerinin risk değerlendirmesi sonucu; tesiste pek çok aktivitenin "çok tehlikeli" sınıfta olduğu tespit edilmiştir. Bu kapsamda özellikle dolum istasyonlarındaki dolum sırasındaki kıvılcım/kaza riskini (Zone 0: gazlı ortam) düşürmek için alınması gereken eylemler/önlemler için işletmeci firma yetkilileri ile görüşülmüş, söz konusu aktivitenin yılda bir değerlendirmesinin yeniden yapılmasına/gözden geçirilmesine karar verilmiştir.

\section{REFERENCES / KAYNAKLAR}

Chinniah, Y., Gauthier, F., Lambert, S. \& Moulet, F. (2011). Experimental analysis of tools used for estimating risk associated with industrial machines. Studies and Research Projects/Report R-684, Montreal, IRSST.

Deming, W. E. (1982). Quality, productivity and competitive position. Cambridge. MA: MIT, Center of Advence Engineering.

Fahlbruch, B. \& Wilpert, B. (2002). System safety: Challenges and pitfalls of intervention. United Kingdom: Emerald Group Publishing Limited.

Fernandez-Muniz, B., Montes-Peon, J. M. \& Vazquez-Ordas, C. J. (2007). Safety Management System: Development and Validation of a Multidimensional Scale. Journal of Loss Prevention in the Process Industries, 20(1), 52-68.

Frick, K. \& W. J. (2000). Reviewing occupational health and safety management-multiple roots. Amsterdam: Elsevier.

Garvey, P. R. \& Lansdowne, Z. F. (1998). Risk matrix: An approach for identifying, assessing, and ranking program risks. Air Force Journal of Logistics, 22(1), 18-21.

Goetsch, D. L. (2008). Occupational safety and health for technologists, engineers, and managers. New Jersey: Pearson Prentice Hall.

Goosen, P. (2005). Management system in OHS, analysis and comparison of OHS management system norms. Ankara: ISAG.

ILO. (2001). Guidelines on occupational safety and health management systems. Geneva: International Labour Office.

İncekara, Ç. Ö. (2018). Ülkemizdeki enerji santral yatırımlarının AHP yöntemi ile değerlendirilmesi. Çukurova Üniversitesi Mühendislik Fakültesi Dergisi, 33(4), 185-196.

İSGIP. (2013). AB ISG yönetim sistemleri iyi uygulamaları. Ankara.

Jallon, R., Imbeau, D. \& De Marcellis-Warin, N. (2011). A process mapping model for calculating indirect costs of workplace accidents. Journal of Safety Research, 42(5), 333-344.

Kamrahi, A. \& Parsaei, H. (1994). A methodology for the design of manufacturing systems using group technology. Production Planning \& Control, 5(5), 450-464.

Khanzode, V., Maiti, J. \& Ray, P. K. (2012). Occupational injury and accident research: A comprehensive review. Safety Science, 50(5), 1355-1367. 


\section{Incekara, Ç. $\ddot{O}$.}

Laitinen, H., Vuorinen, M., Simola, A. \& Yrjänheikki, E. (2013). Observation based proactive OHS outcome indicators-validity of the elmeri+ method. Safety Science, 54, 69-79.

Mamdani, E. \& Assilian, S. (1975). An experiment in linguistic synthesis with a fuzzy logic controller. International Journal Man-Machine Studies, 7(1), 1-13.

Marhavilas, P., Koulouriotis, D. \& Gemeni, V. (2011). Risk analysis and assessment methodologies in the work sites: On a review, classification and comparative study of the scientific literature of the period 2000-2009. Journal of Loss Prevention in the Process Industries, 24(5), 477-523.

MIT. (2004). A guide to job flexibility at MIT: Tools for employees and supervisors considering flexible work arrangements. Center for Work, Family \& Personal Life. http://hrweb.mit.edu/system/files/all/worklife/flexible_work_arrangements.pdf

National Safety Council-NSC. (1980). Accident prevention manual for industrial operations.

OHSAS 18001. (1999). Occupational health and safety management systems.

Rantanen, J. (2010). Grand challenges for occupational health from globalization. Journal of Occupational Safety and Health.

Robson, L. C. J. (2005). The effectiveness of occupational health and safety management systems: A Systematic review. Institute for Work and Health.

Roslin, E. N. \& Seang, O. G. (2008). A study on facility layout in manufacturing production line using WITNESS. Proceedings of the 9th Asia Pasific Industrial Engineering \& Management Systems Conference, Nusa Dua, BaliIndonesia.

Saaty, T. L. (1980). The analytic hierarchy process. New York, ABD: McGraw-Hill.

Shikdar, A. A., \& Sawaqed, N. M. (2003). Worker productivity and occupational health and safety issues in selected industries. Journal of Computers \& Industrial Engineering, 45(4), 563-572.

Tompkins, J. A., White, J. A., Bozer, Y. A., Frazelle, E. H., Tanchoco, J. M. A. \& Trevino, J. (2010). Facilities planning. United States of America: John Wiley and Sons Inc.

University College London-UCL. (2000). A guide to safety maintenance operatives handbook. Health \& Safety at Work Act 1974. http://www.ucl.ac.uk/efd/maintenance/construction/handbooks/MAINTOP2000A4.pdf

Waeyenbergh, G. \& Pintelon, L. (2002). A framework for maintenance concept development. International Journal of Production Economics, 77(3), 299-313.

Walter, K. F. (2000). Workers participation and the management of occupational health and safety: Reinforcing or conflicting strategies. Oxford: Pergamon.

Wang, J. X. (2010). Lean manufacturing: Business bottom-line based. ABD: CRC Press.

Wang, J.-W., Cheng, C.-H. \& Kun-Cheng, H. (2009). Fuzzy hierarchical TOPSIS for supplier selection. Applied Soft Computing, 9(1), 377-386.

Wassell, J. T. (2008). A literature review and synthesis of the current methods of risk identification in the workplace. The National Institute for Occupational Safety and Health.

Work Safe-WF. (2007). Machinery and equipment safety: An introduction. Department of Consumer and Employment Protection Government of Australia. http://www.commerce.wa.gov.au/worksafe/PDF/National_Standards/VWA_Machine_Safety_l.pdf 